\title{
Perceived Impacts of Climate Change on Economic Activities and Adaptation Strategies: A Case Study from Cold Desert of Ladakh, India
}

\author{
Tsering Tashi* ${ }^{\circledR}$, Falendra Kumar Sudan \\ Department of Economics, University of Jammu, Jammu, Jammu and Kashmir, India \\ Email: tashit202@gmail.com
}

Received: 30 July 2021; Revised: 15 November 2021; Accepted: 17 November 2021

\begin{abstract}
This paper aims at identifying the perception of local indigenous Peoples' living in the cold desert area of Nubra valley (Ladakh), India, on climate variability resulting in extreme events such as floods and cloudbursts and their impacts on various economic activities such as agricultural productivity, land degradation, soil erosion, water availability, and forest resources. It also aims to ascertain the vulnerability of the key sectors such as forest, agriculture and water sources, and local adaptation strategies to adapt to climate variability and extreme events. Stratified random sampling technique was adopted to select the sample size. The study is based on the primary data and information collected from 288 sample households in three blocks i.e., Diskit, Panamik, and Turtuk through semi-structured interviews, questionnaires, focus group discussions, and PRI tools. Study findings revealed that more than 90 percent of overall households' respondents of three blocks observed that temperature has been increased and low rainfall/snowfall over the last three decades. The result showed that the majority of respondents admitted that land degradation, severe soil erosion and shortage of water, low agricultural productivity, and decline in forest resources are major climaterelated problems due to low rainfall/snowfall, increase temperature, and natural disasters. To alleviate these problems, local people have implemented various adaptation strategies such as mixed farming, more plantations of trees, organic farming, and changing crop patterns. The policy recommendations for appropriate adaptation strategies are in consideration with the knowledge of local indigenous peoples and their perception of climate change. The study could be helpful to policymakers to design appropriate adaptation strategies to cope up with the impacts of climate change.
\end{abstract}

Keywords: adaptation strategies, vulnerability, climate change, perception, natural disaster, Nubra valley

JEL Code: C83, Q23, Q24, Q25, Q54

\section{Introduction}

Climate change is considered as a global challenge and it has become the key environmental issue around the world (Hussain et al., 2021), and the average surface temperature has increased by $0.85{ }^{\circ} \mathrm{C}$ over the past 100 years (IPCC, 2018), and it is predicted to increase further by at least $1.5^{\circ} \mathrm{C}$ by the end of the 21 st century, with serious consequences for biodiversity, natural ecosystems, agriculture productivity, food security and human livelihoods (IPCC, 2019).

Copyright (C2021 Tsering Tashi, et al.

DOI: https://doi.org/10.37256/redr.2220211068

This is an open-access article distributed under a CC BY license

(Creative Commons Attribution 4.0 International License)

https://creativecommons.org/licenses/by/4.0/ 
Climate change is the biggest environmental threat facing the world due to increasing temperature, the unpredicted pattern of rainfall and snowfall (Marzeion et al., 2020). The glaciers of the Himalayas are receding, thinning, and shrinking as the planet warms and its impacts are more serious to the mountainous people because they heavily depend on the glacier meltwater for their irrigation and drinking purpose (Sharma et al., 2019).

Agriculture, forest, and water resources are the key sources of food production and livelihoods of the inhabitant of the mountain areas. Mountain agriculture is highly sensitive, and many difficult challenges have been facing due to its harsh climate (Falco et al., 2012), and due to any kind of climatic change have a major effect on their crop yield, and food supply in the Himalaya region (Berrang et al., 2014). Despite that, most of the people are engaged in agricultural production for their livelihoods.

Local people have deep experiences about the impacts of climate change (Parry et al., 2007). Mountainous peoples have various indigenous methods to come back to the impacts of climate change and its impact can be altered into a source of livelihoods by using the potential adaptation strategies. The adaptation strategies seem to be the most efficient strategy to uplift the source of income of the rural farmers (Dannevig \& Hovelsrud, 2015). Similarly, traditional knowledge and experiences of local farmers on local environment can be accepted as a practical contribution to mitigating the environmental problems and possible solutions for the impacts of climate change, and it also helps to develop adaptive capacity and resilience to climate change (IPCC, 2007; Weber, 2010).

The cold desert area of the Ladakh region is one of the most fragile and sensitive to the impact of climate change due to its harsh climate and high dependence on natural resources for their livelihoods (Hewitt, 1998). Any change in the climatic variables such as increasing temperature and declining rainfall or snowfall directly affects the source of water of mountain people. Furthermore, the Khardungla glacier in Nubra valley has receded by $19.5 \mathrm{~km}$ and is on the threshold of extinction (Gupta et al., 2012). Therefore, the variability of climatic factors such as rising temperature is one of the major causes of receding glaciers and increasing natural disasters in the western Himalayas. It results in massive losses, damages of properties, assets, and even losses of human life (Kumar et al., 2013). It has also retarded their economy, social, and livelihoods due to which they become more vulnerable, with high sensitivity, and low resilience to the impacts of climate change (Chevuturi et al., 2018).

Variability of temperature and irregular rainfall are the main cause of natural hazards (Tripathi et al., 2014). For instance, on August 6, 2010, the shocking flash floods had happened in the surrounding region of Leh town and Turtuk block in Nubra valley which had killed 255 people, affected 52 villages, and destroyed 1,749 houses in the region and the rage of the flash floods caused serious damages to the roads, bridges, hospitals, and crops, etc. As a result, it has directly affected the livelihoods of the people and their food security (Tashi, 2010).

The most appropriate way to understand the climate change adaptation mechanisms requires a reliable knowledge of the vulnerability background and local ground realities, which is difficult to comprehend without taking into consideration of indigenous knowledge and experiences of local inhabitant communities which have empowered them to cope with extreme weather and environmental change over centuries. Thus, a better understanding of the farmers' perceptions about climate change impacts and their ongoing adaptation mechanisms are needed to expertise and consideration through the development of policies and strategies for better rural economy and less adverse impacts of climate change to the rural farmers (Chaudhary \& Bawa, 2011; Lechowska, 2018). Therefore, the main objective of the present study was to examine the local people's perception and their traditional knowledge on climate change, its impacts on various economic activities, and to understand the degree of key sectors climate vulnerability and how they cope up and adapt to climate change impacts and to strengthen the adaptation strategies to reduce their vulnerability in the Himalayan region of Nubra valley.

\section{Literature review}

Himalayan mountains are represented as one of the highest mountain ranges of the world and it has rich in biodiversity and glaciers (Williamson et al., 2020), besides, important sources of water to the Asian countries which are popularly known as the water tower of Asia (Xu \& Grumbine, 2014). The inhabitant of Himalayan mountain communities who are heavily dependent on glacier meltwater for irrigation and drinking purposes and their rural subsistence economy is also based on natural resources (Belay et al., 2017). Natural resources such as land, water, and forest resources are the main significant role in agriculture, horticulture, and livestock production and are the primary 
occupation of mountain communities for their livelihoods, and outcome of these productions fully relies on climatic variables such as temperature and pattern of precipitation.

Thus, due to the variability of climatic factors such as temperature, and unpredicted rainfall has directly affected the livelihoods and economy of the mountain communities (Liedtke et al., 2020), and it has also been evident from several studies that the negative impacts of climate change like natural disasters such as floods, and cloudbursts had frequently occurred in the hilly area compare to other areas in the last decades (Pandey et al., 2017).

Climate change and its impact are more apparent in the mountain region of Himalaya, Andes Mountain, and Tibetan Plateau and it is considered that the inhabitant of the hilly areas are facing various kinds of problems and need to pay attention in a priority (Gao et al., 2019).

The inhabitants of the Himalayan regions are more vulnerable to climate change as compared to other regions (Khanal et al., 2018), and the Intergovernmental Panel on climate change (IPCC) reports that the impacts of climate change are more on agricultural activities of hilly areas (IPCC, 2014b), mostly affected after the 1990s, because of the rising trend in temperature, decline trend in rainfall/snowfall and extreme events (Paudel et al., 2016). Several studies show that impacts of climate change differ from region to region and are a more severe threat to the hilly areas due to their fragile and sensitive environment (Shrestha \& Aryal, 2011). Agriculture and climate change are a close relationship and any climate change can have substantial impacts on crop yield and agriculture become more sensitive (Probstl, 2016). Studies expressed that climate change will negatively be affected the hilly areas of agriculture by a 3-7\% reduction in the yields of wheat, mustard, barley, and potato with every one-degree increase in temperature (Aase \& Chapagain, 2017).

Climate variability is one of the key factors influencing local adaptation strategies in the rural areas where agriculture is the prime source of income for the rural people and their livelihood (Dieye \& Roy, 2012). Farmers have been changing their crops patterns such as crop rotation, mixed farming, water allocation policies, planting trees, reducing tillage, planting cover crops and reintegrating livestock into crop production systems to adapt to the impacts of climate change or changing climatic conditions (Simelton et al., 2013). Farmers, being sensitive to the impacts of climate change, are using local adaptation strategies to reduce the climate risk (Rufat et al., 2020). Thus, it is essential to understand the farmers' perception of climate variability and information about the local environment and weather pattern to grasp the concrete knowledge for the advancement of policymaking and programs (Mertz et al., 2011).

Decreasing precipitation, erratic rainfall, more frequent floods, soil erosion, the difficulty of tillage and poor transportation facilities make it more challenging for agriculture production. Farmers have been modifying some of the topographical factors to some extent by manual efforts. For example, they carry water to land where there is little rain or supply fertilizers to the soil that is deficient in plant food. So, the applied techniques of crop production by farmers and the real challenges that they face can contribute a lot to comprehending the severity of climate change and can be used to find out new farmer-friendly adaptation strategies and policies (Chapagain et al., 2017).

Depending upon the water availability, soil conditions, variation in temperature and moisture, farmers at different regions face altogether different challenges. Accordingly, solutions to adapt and mitigate climate change are site and regional-specific. Therefore, considering the viewpoints of region specified farmers would help to develop a holistic approach to mitigate numerous risks of changing climate.

Some parts of the Himalayan region satisfactorily mitigate the impact of climate change by using various adaptation mechanisms such as rotating crops, mixed farming, adjusting planting times (early and late) and crops diversifications (Negi et al., 2017). If the national policies support the climate change responses, the adaptive capacity which is already being applied by the local peoples can be improved (Carman \& Zint, 2020).

Mountain people who are mainly dependent on agriculture and subsistence farming for their livelihoods are vulnerable and challenged to the effects of climate change (IPCC, 2018). The adaptation responses in such communities in the Himalayas are insufficient due to a lack of resilience or resources and a fragile environment (Mitter et al., 2019).

Several studies revealed that the role of local indigenous people and their knowledge in handling and tackling the adverse impacts of climate changes are very significant and it can be helpful to achieve the solution and effective adaptation (McDowell \& Hess, 2012). Individual adaptation strategies to protect their households from the negative impacts of climate change in the communities. Moreover, this kind of positive individual technique can give more beneficial outcomes to reduce the vulnerabilities and to improve the climate resilience and adaptation mechanisms in the community (Carman \& Zint, 2020), and government should intervene in these considerations and encourage the local 
indigenous techniques through various incentive methods (Jarawura, 2014), and this kind of individual sound steps can lead to more positive externalities in the societies (Van \& Steg, 2019). Furthermore, the integration of both scientific knowledge and local indigenous peoples' perception is the most effective adaptation strategies to cope up with the impacts of climate change and to reduce the climate risk vulnerabilities.

\section{Research gaps}

Ladakh has a unique cold arid climate with unusual precipitation, and scarce vegetation in the Trans-Himalaya and is considered as a "hotspot" of climate change impacts. Therefore, the issues of vulnerability, exposure, adaptive capacity, and adaptation strategy need to be understood in a local context in the communities.

Several studies have been worked on the perceived impacts of climate change and adaptation strategies in India and some other countries also. But no such studies have been done on the perceived impacts of climate change, and adaptation strategies focusing on land degradation, soil erosion, and availability of water, forest resource, livelihoods of population, and their coping and adaptation mechanism in the Nubra valley of Ladakh. From the above, it is clear that none of the studies have been conducted on "Perceived impacts of climate change on economic activities and adaptation strategies in the cold desert of Ladakh, India". Thus, the present study will be a medium attempt to fill the data and information gaps in this vital area of research, which will also be useful for drawing significant policy implications for the sustainable development of Nubra valley in Ladakh, specifically in the context of climate change impacts and their adaptation mechanism. This will also provide some policy recommendations for Government and Non-Government agencies for implementing climate resilience policies and programs.

\section{Objectives and methodology}

The main objectives of the present study are as follows:

- To identify the local peoples' perception on climate change in the Nubra valley.

- To examine the perceived impacts of climate change on various economic activities and to ascertain the climate risk vulnerability of three key sectors such as forest, agriculture, and water resources in the Nubra valley.

- To understand how local people use adaptation strategies to cope up with the impacts of climate change and to reduce climate vulnerability in the Nubra valley.

\subsection{Information on climate change assessment}

A mixed-method was used i.e., qualitative and quantitative methods to comprehend the people's perceptions and traditional environmental knowledge on climate change. Understanding about the impact of climate change on various economic activities i.e. agricultural productivity and availability of water and forest resources was collected through household surveys, focus group discussions, and PRA tools i.e. group discussion, historic information, etc. Local indigenous knowledge is a process of practices, beliefs, and understanding about the local environment. To alleviate this problem, local people developed various adaptation strategies through their indigenous knowledge based on past experiences and learning under local climatic conditions. Surveys were carried out in the Ladakhi language because most of the respondents preferred to speak in the local language (Ladakhi).

\subsection{Sampling design}

The statistical population was composed of different areas of Nubra valley. To improve the accuracy of sampling and to incorporate statistical population features in the sample, the stratified sampling method was adopted in which the entire population was divided into different subgroups or strata, and then selections were randomly made proportionally from the different strata. A stratified sampling technique often requires a smaller sample, which saves money and efficiency. Since the Nubra valley consists of three different areas or blocks, 288 samples of the households were gathered out of 3606 households in these three blocks or strata, including 137 from the Diskit block, 85 from the 
Panamik block, and 66 from the Turtuk block. Meanwhile, the sample size of each block was determined by using the (ni) formula. The sample size of each block was enough and truly represented the population. The sample size has been selected by using the formula $\left(\mathrm{ni}=\mathrm{Ni} / \mathrm{N}^{*} \mathrm{n}\right)$. Sampling details are shown below.

Table 1. Total population (N), Strata ( Diskit, Panamik and Turtuk), Sample size (n), and Formula (Ni/N*n).

\begin{tabular}{cccc}
\hline Region & Sub-groups & Statistical Population $\left(\mathrm{N}_{\mathrm{i}}\right)$ & Sample Size (ni) \\
\hline Diskit & 1715 & 137 \\
Nubra Valley & Panamik & 1065 & 85 \\
& Turtuk & 826 & 66 \\
& Total & $\mathrm{N}=3606$ & $\mathrm{n}=288$ \\
\hline
\end{tabular}

Source : Village amenity directory, (2015-16), Leh

\subsection{Qualitative and quantitative assessments}

Qualitative and quantitative approaches were used which are based on exploratory research to understand the perception of local people on climate change and its impact in the region. Open-ended questions were used to cover a wide range of information through group discussions and meetings conducted at the village level to establish the general perceptions regarding climate change impact in the study area (Negi et al., 2017)

Descriptive research was used and household data were collected through closed-ended questions i.e. local peoples' perception and knowledge towards climate variability and its impacts, vulnerabilities and adaptation strategies adopted by local people. This was further updated and verified with the data generated through the qualitative methods (Maikhuri et al., 2003; Rao et al., 2012). Information was collected through a questionnaire based approach on various economics activities and the vulnerability of three key sectors of forest, agriculture and water resources and local adaptation measures adopted to cope up with the climate change impacts.

\subsection{Overview of the study area}

The present study was undertaken in Nubra valley lies between the two great mountain ranges-the Ladakh (on the South) and the Karakoram (on the North). The valley located between $34^{\circ} 15^{\prime} 45^{\prime}$ to $35^{\circ} 31^{\prime} 00^{\prime} \mathrm{N}^{\prime}$ and $76^{\circ} 55^{\prime}$ to $78^{\circ} 05^{\prime}$ E co-ordinates (Kumar et al., 2009) and is located in the cold desert area in Karakorum Mountain range of Himalaya in the Union Territory of Ladakh, India (Figure 1). There are two main rivers i.e., Nubra river (a tributary of Shayok river) and originates from the Siachen glacier, the second-longest non-polar glacier in the world, and the Shayok river (a tributary of Indus River) and originates from the Remo glacier (Joshi et al., 2006). The glacier meltwater is the key source of water for irrigation and drinking purposes. Nubra valley is known for the richness of natural resources in the history of Ladakh due to its fertile area and the rural populations of the region are fully dependent on agriculture production, horticulture production, and forest resources for their livelihoods. Likewise; the region is characterized by an agricultural subsistence economy in which they are cultivating various kinds of crops as compared to the rest of the Ladakh region due to its fertile area. Besides, the valley is also known as a climate-prone area due to the frequent natural disasters that have been occurring in past decades (Table 2). The survey was carried out in the three mountainous blocks viz. Diskit, Panamik, and Turtuk of Nubra valley in a cold arid area of Himalaya. 


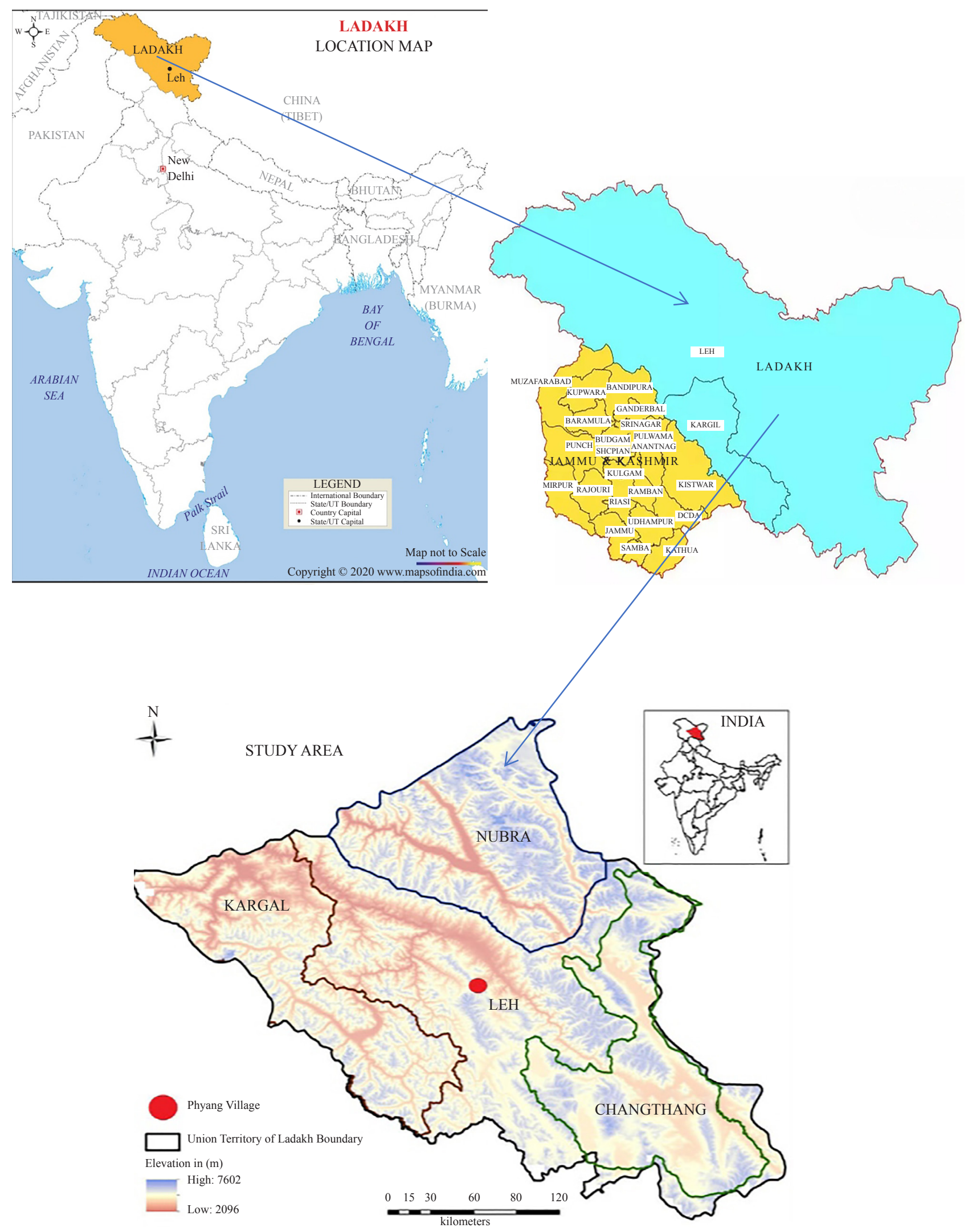

Figure 1. Map of the study area 
Table 2. Natural disasters have occurred over last one decade in Nubra valley

\begin{tabular}{cccc}
\hline Year & Type of natural disasters & Village & Block \\
\hline 2010 & Cloudburst and Flashflood & Turtuk and Takshi villages & Turtuk \\
2015 & Glacier Lake Outbursts flood (GLOFs), & Tegger, Udmaru, Hundri, Diskit and & Khalsar villages \\
2019 & Flood and cloudburst & Waris, Charasa, and Burma villages & Diskit and Panamik \\
2020 & Flashflood and Flood & Hundri village & Diskit \\
\hline
\end{tabular}

Source: Field Survey

\section{Results}

\subsection{Farmers'perceptions towards climate change or variability}

Analysis of farmers' perception of climate change is a precondition for evaluating the climate change impacts, vulnerabilities and their adaptation strategies. Data obtained from the survey indicated that more than $90 \%$ of the total respondents of three blocks were acknowledged and observant of significant alterations in weather patterns over the last three decades (Table 3). During the focus group discussion, the local respondents are confident that the climate has changed, not because they know much about global warming and scientific knowledge about the process of climate change but due to their past experience about the local environmental change and also their long experience in the agricultural farming. In this present study, most of the respondents were farmers' and data were purposively collected from the head of the households to know about their past indigenous knowledge and experience about the reality of local environment or climate. Thus, the study result clearly indicates that weather pattern has been changing over the past three decades, because of which the variability of climate is also changing in the study area (Table 3 ).

Table 3. Farmers perception towards weather changes over past three decades in the Nubra valley

\begin{tabular}{cccc}
\hline & & \% of respondents & Panamik \\
\cline { 2 - 4 } Response & Turtuk & Diskit & 90 \\
Yes & 98 & 93 & 10 \\
No & 2 & 7 & 100 \\
\hline
\end{tabular}

Source: Field Survey

The changing of climatic factors is validated by the local indigenous farmers, and they can be perceived the fluctuating trends of climatic variables such as temperature, rainfall, and snowfall with the help of their past extensive experienced, and knowledge about the local environment and above $90 \%$ of the respondents from each block perceived that the nature of the precipitation is changing (Table 4). They have observed, the month of peak rainy seasons started around the middle of July in the past, whereas now it has changed and shifted to the third week of August.

The study results indicate that $99 \%$ respondents of Turtuk block, 98\% respondents of Diskit block and $96 \%$ respondents of Panamik block observed that temperature has been increasing over the last three decades, the summers have become hotter and the frequency of natural disasters has increased in the region. Based on analysis, during the focus group discussion the local people have highlighted the core issues which they have faced due to changing climate patterns such as the decrease in rainfall and snowfall. Similarly, the study found that more than $90 \%$ respondents of the three blocks acknowledged a decrease in the rate of rainfall and snowfall (Table 4). Due to decline in rainfall and 
snowfall, the availability of water is reduced and it leads to negative impacts to the people of Nubra valley as glacier melt water is the only source of water for their irrigation and drinking purpose. In the present study, $87 \%$ respondents of Turtuk block, $80 \%$ respondents of Diskit block and 94\% respondents of Panamik block respectively were observed that the availability of water has been declining in the Nubra valley of Ladakh (Table 4).

Table 4. Peoples' perceptions on indicators of climate change in Nubra valley of Ladakh

\begin{tabular}{|c|c|c|c|c|}
\hline \multirow{2}{*}{ Indicators } & \multicolumn{4}{|c|}{$\%$ of respondents } \\
\hline & Response & Turtuk & Diskit & Panamik \\
\hline \multirow{2}{*}{ Change in nature of precipitation } & Yes & 91 & 94 & 90 \\
\hline & No & 9 & 6 & 15 \\
\hline \multirow{2}{*}{ Decrease in water availability } & Yes & 87 & 80 & 94 \\
\hline & No & 13 & 20 & 6 \\
\hline \multirow{2}{*}{ Decrease in snowfall } & Yes & 97 & 94 & 96 \\
\hline & No & 3 & 6 & 4 \\
\hline \multirow{2}{*}{ Increase in temperature } & Yes & 99 & 98 & 96 \\
\hline & No & 1 & 2 & 4 \\
\hline \multirow{2}{*}{ Decrease in rainfall } & Yes & 95 & 97 & 91 \\
\hline & No & 5 & 3 & 9 \\
\hline \multirow{2}{*}{ Has the climate changed? } & Yes & 81 & 76 & 88 \\
\hline & No & 19 & 24 & 12 \\
\hline
\end{tabular}

Source: Field Survey

\subsection{Impacts of climate change on various economics activities}

Agriculture is the main activity of people living in Nubra Valley as it provides food and livelihood security. However, any variability of climate has directly impacted agricultural productivity and sustainability. The study revealed that $78 \%$ respondents of Turtuk block, $83 \%$ respondents of Diskit block and $71 \%$ respondents of Panamik block realized that the productivity of agriculture had decreased due to the impacts of climate change (Figure 2). Furthermore, the irrigation and productivity of agriculture depend on the supply of glacier melt water. Any change in the supply of water leads to a serious threat to agriculture production, and therefore to the livelihoods, economy, and food security of the region. Also, 71\% respondents of Turtuk block, 78\% respondents of Diskit block, and $80 \%$ respondents of Panamik block have revealed that the availability of water has decreased in their areas respectively due to the impact of climate change (Figure 2). Therefore, the reduction of water availability is one of the main driving forces for reducing agricultural productivity in the region.

Local farmers experienced that the impacts of climate change on agriculture production have two aspects i.e., negative and positive both. The traditional staple crops of food grain such as wheat and barley and fruits such as apricots and walnuts have been adversely affected due to rising temperature and its productivity has been decreasing. Whereas, various cash crops are being cultivated now due to increasing temperature which couldn't have been cultivated in the past due to harsh climate or weather in the cold arid mountain area. Thus, an increase in temperature helps to raise many agricultural productions which are difficult to cultivate in a cold place. But the magnitudes of negative impacts of climate change are much higher in the mountain area of Nubra valley. There have frequently increased climate Hazards like cloudbursts, floods, flash floods, and global lake outburst floods (GLOFs) in the Nubra valley. Local people have 
witnessed that the recurrence of natural disasters has been happening almost every alternate year in the last decade (Table 2). Natural events have negative impacts on various economic activities and their livelihoods. The study results indicate that $81 \%$ respondents of Turtuk block, $75 \%$ respondents of Diskit block and 87\% respondents of Panamik block perceived that land degradation and soil erosion has increased due to the impact of climate change (Figure 2) which has led to a serious threat to their livelihoods.

(a)

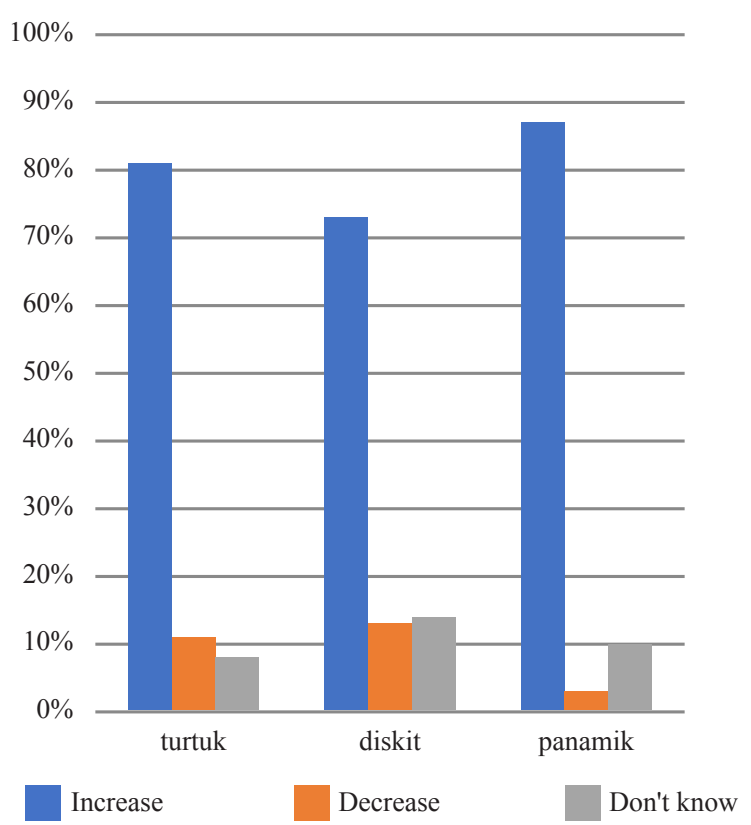

(c)

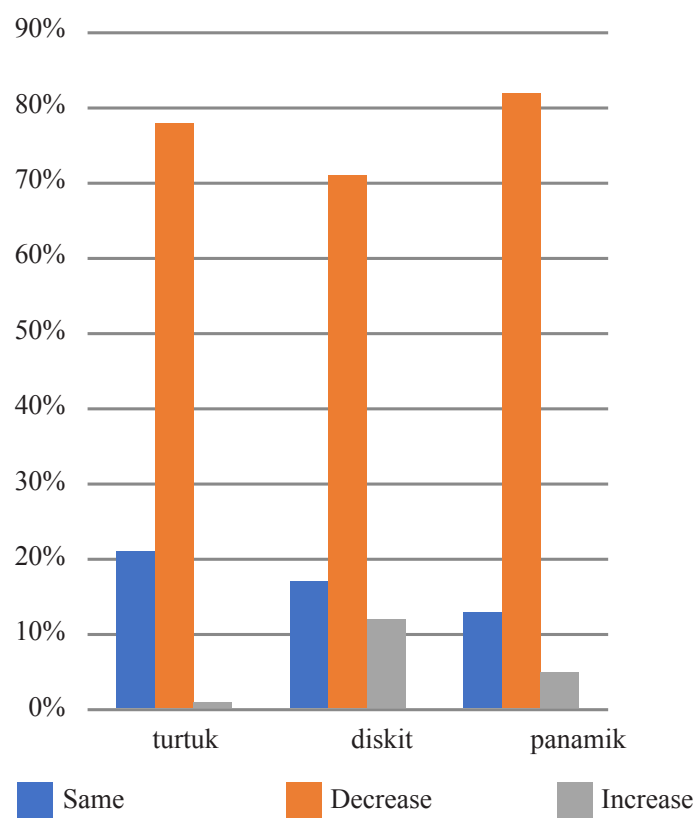

(b)

Water availability

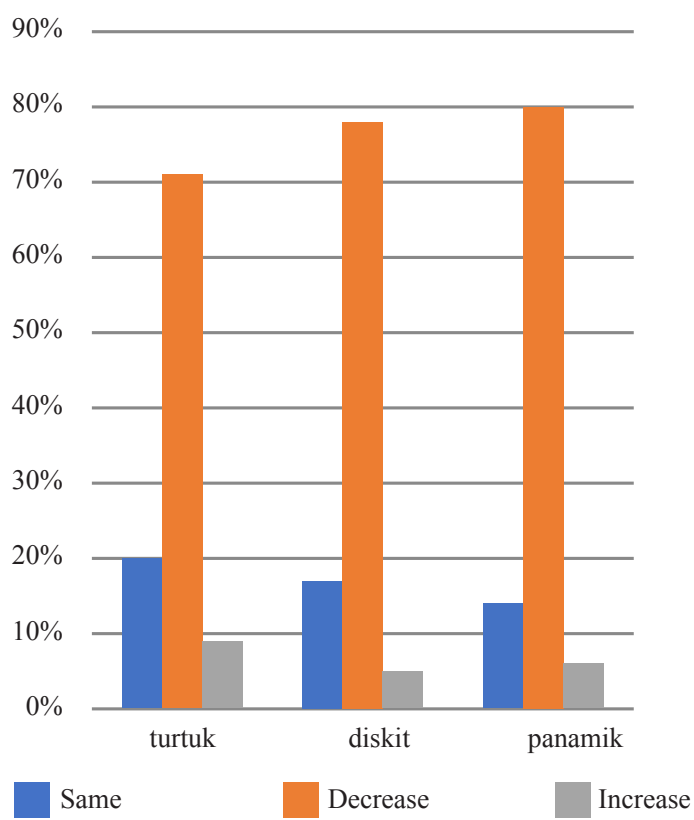

(d)

Agricultural productivity

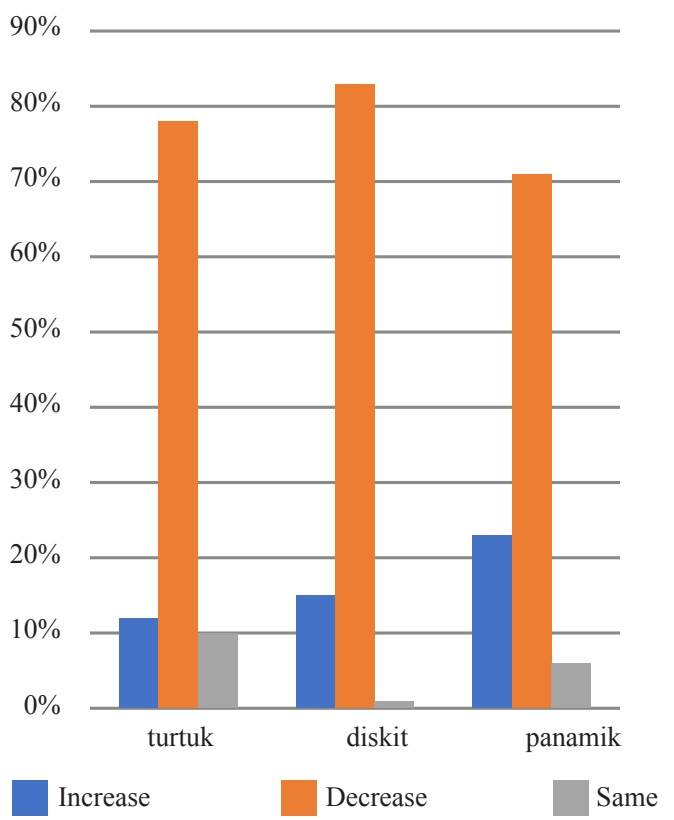

Figure 2. Farmers' perception of climate change impacts on various economic activities in the Nubra valley 
In the cold desert area, constitute of forest resources is less as compared to the other regions and forest resources is a major role to sustain their life and increase livelihoods. But the impact of climate change has threatened the forest resources of the mountain communities. Similarly, the study revealed that $78 \%$ respondents of Turtuk block, $71 \%$ respondents of Diskit block and $82 \%$ respondents of Panamik block were experienced that the forest resource availability has declined due to the impacts of climate change in the Nubra valley. Furthermore, most of the forest resources are found on the riverside and the rivers, streams located in villages of three blocks have been severely affected because of climatic disasters such as floods and glacier lake outburst floods (GLOFs) in the region. These climatic disasters, therefore, make the livelihood of the people more susceptible in Nubra valley as it is already vulnerable to scanty natural resources.

\subsection{Climate risk vulnerability of three key sectors}

Climate risk vulnerability is the degree to which a structure is vulnerable to and unable to cope up with adverse effects of climate change, climate variability and extremes (IPCC, 2007a). Vulnerability can be measured using three dimensions of exposure, sensitivity and adaptive capacity to the effects of climate change. The adaptive capacity refers to the ability to respond to exposure and sensitivity to reduce adverse impacts and to develop resilience. While exposure is, the presence of people, livelihoods, environmental functions, ecosystems, resources, economic, social and cultural assets in places that could be adversely affected by climate events and sensitivity is the degree to which the system is affected by the exposure to risk (IPCC, 2019).

\subsubsection{Forest vulnerability}

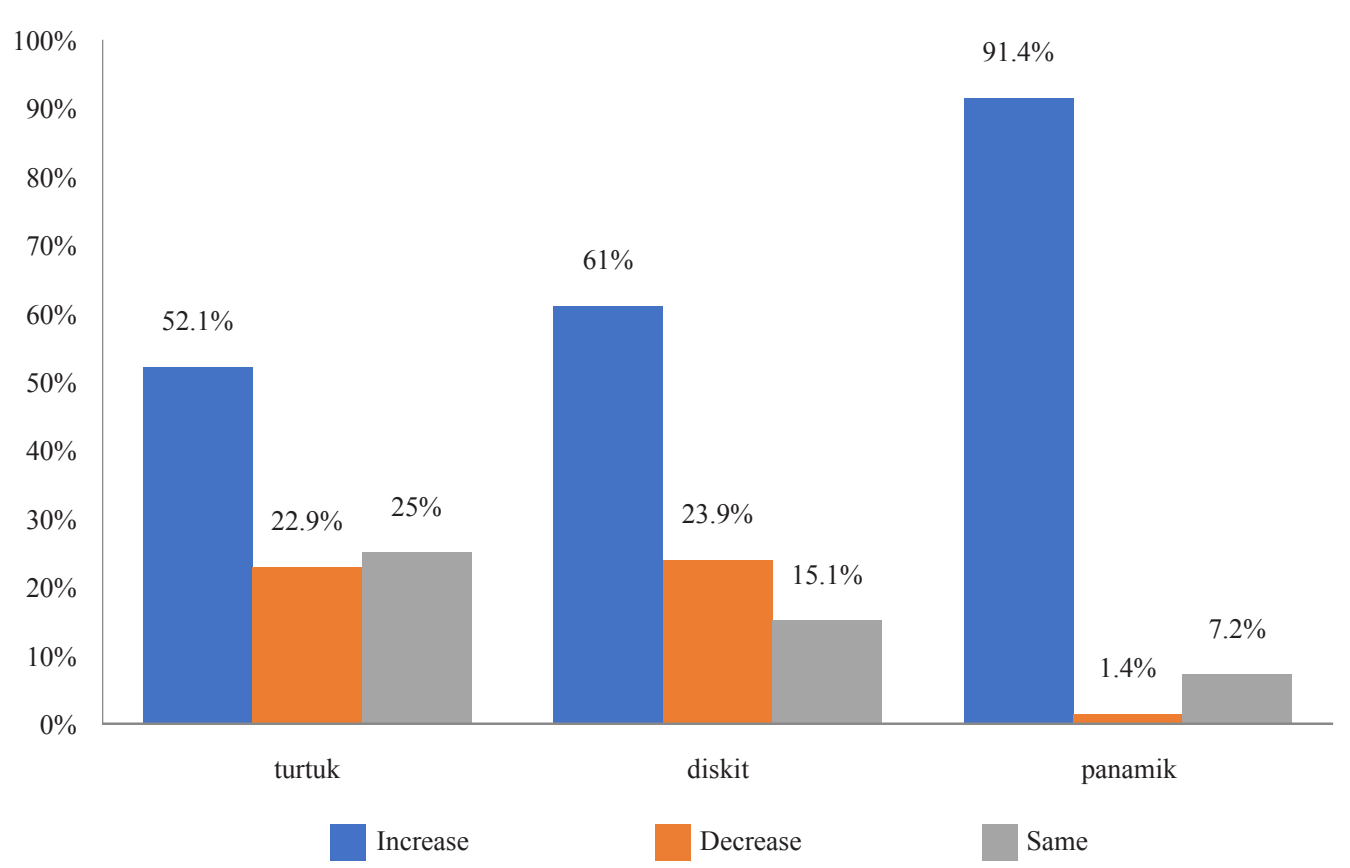

Figure 3. Forest vulnerability

The forest resources such as plants, trees, sea buckthorns and grasses are the major sources of livelihood of the rural people of Nubra valley. Increasing forest vulnerability due to the impact of climate change varies from region to region. Due to the variability of climatic factors such as increasing temperature and erratic rainfall and snowfall, the forest resources become more vulnerable. The study result shows that $91.4 \%$ respondents of Panamik block admitted that the impact of climate change on forest resources is a serious problem and frequent natural disasters particularly 
global lake outburst floods (GLOFs) due to increasing temperature is the major cause of the forest vulnerability in the Panamik block (Figure 3). Due to that forest land has degraded and has led to adverse effects to the poor people who fully depend on forest resources for their livelihoods. Global lake outburst flood (GLOFs) is an indicator of exposure and higher forest vulnerability due to increasing temperature in the Panamik block. Similarly, $52.1 \%$ and $61 \%$ respondents of Turtuk and Diskit blocks respectively revealed that forest vulnerability has increased due to less rainfall and snowfall and it leads to increase water deficiency to the plants, grasses and trees in the forest (Figure 3). It shows that water deficiency in plants, grasses and trees are an indicator of exposure and higher vulnerability due to less rainfall and snowfall.

Whereas, $22.9 \%$ and $23.9 \%$ of local household respondents of Turtuk and Diskit blocks, respectively admitted that forest vulnerability has declined due to increasing temperature (Figure 3). The people in these two blocks have planted more trees in the hilly area and, thus have a positive impact on pastureland, trees and sea buckthorn in the forest due to rising temperature and they earn some money by selling these forest resources such as sea buckthorn in the market. So, planting trees, pasture land and sea buckthorn are an adaptive capacity indicator due to increasing temperature and forest vulnerability is lower in the Turtuk and Diskit blocks. Thus, the results clearly indicate that the forest vulnerability is higher in the Panamik block as compared to Turtuk and Diskit blocks. To reduce the impact of climate change and also to reduce the forest vulnerability plantation of more trees moderates the adverse impact of climate change.

\subsubsection{Agriculture vulnerability}

People primarily depending on agriculture for their livelihoods in the rural areas have a direct relationship with the climatic variable with respect to daily agricultural activities. Any change in the climatic variables directly affects the agricultural production both in the short-run and long-run periods thus affecting the status of food security to the poor people.

In the present study, the result shows that agriculture vulnerability is high in all three blocks of the study area (Figure 4). The vulnerability of traditional crops of wheat and barley and traditional fruits such as Apple, Apricot and Walnut productions are very high due to the climate variability such as increasing temperature which in turn leads to an increase in new crop-related diseases thus affecting the productivity of the crops. The production of these crops is declining and is thus categorized as vulnerable crops and fruits in the study area.

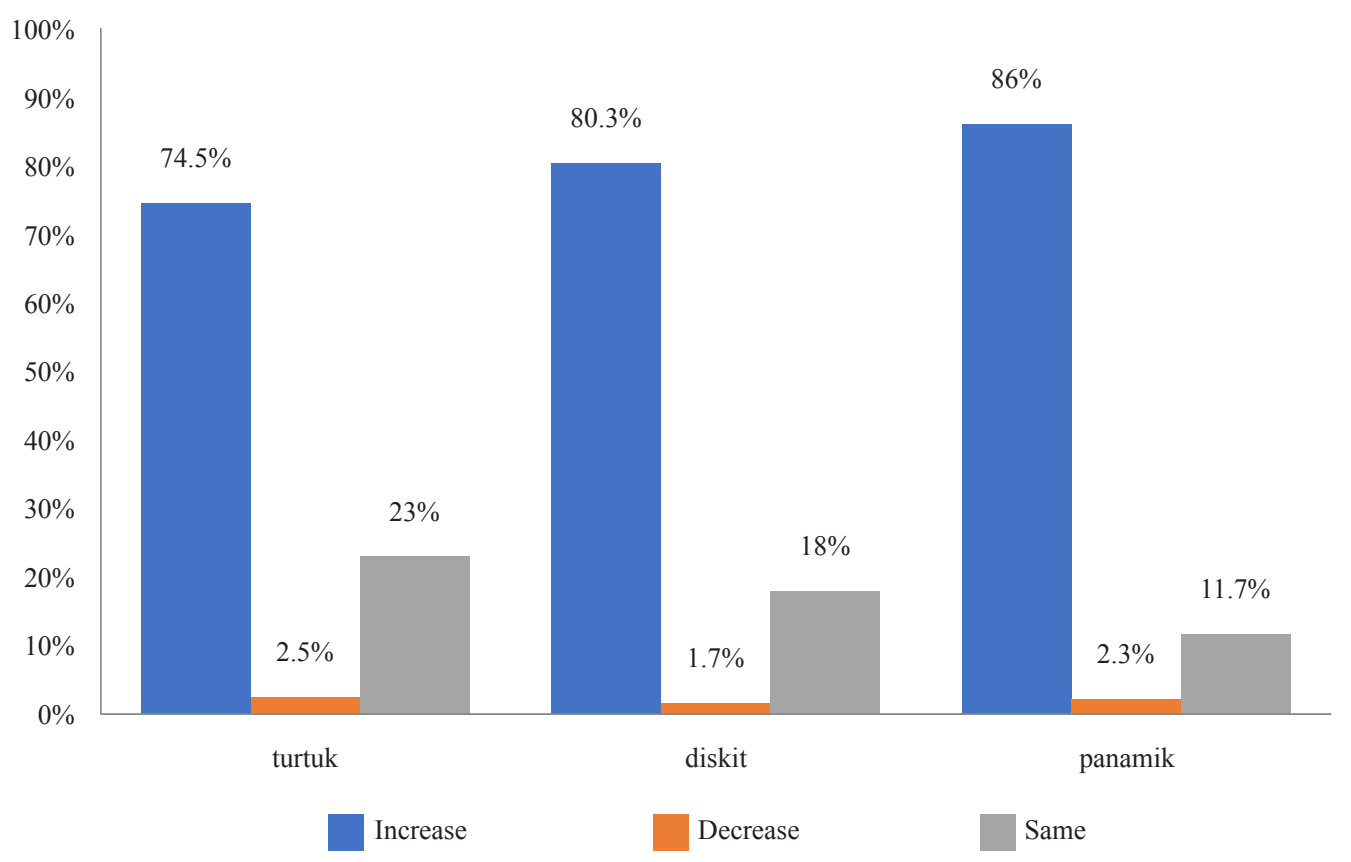

Figure 4. Agriculture vulnerability 
Hailstorm in late spring has badly affected the apricot production particularly during the flowering and budding season. The late snowfall also affects the process of pollination of the fruit plants in the study area. Higher agricultural vulnerability is observed in the Wheat, Barley, Apricot, Apple and Walnut due to the climate variability.

Whereas some local respondents revealed that due to rising temperature, they are cultivating various kinds of cash crops and fruits which were not cultivated in the past due to harsh climatic conditions in the hilly areas (Figure 4). The cultivation of different crops has significantly improved their sources of income and has thus improved their standard of living. The new cash crops that are now produced by the locals are Brinjals, Capsicums, Cucumbers, Peas, Broccoli, Tomatoes, Chili, Mustard, Kala Masoor (Pulses), etc. The new fruits are Grapes, Almonds, and Watermelons. All these new crops and fruits are an adaptive capacity indicator due to rising temperature and lower agricultural vulnerability in a cold desert area of Nubra valley.

\subsubsection{Water vulnerability}

Water is a serious problem of the rural people of Nubra valley because glacier meltwater is the only source of water and demand for water has been rising in the study area for different purposes such as irrigation, drinking and other purposes. The variability of climate such as rising temperature and scanty rainfall leads to more stress towards water vulnerability.

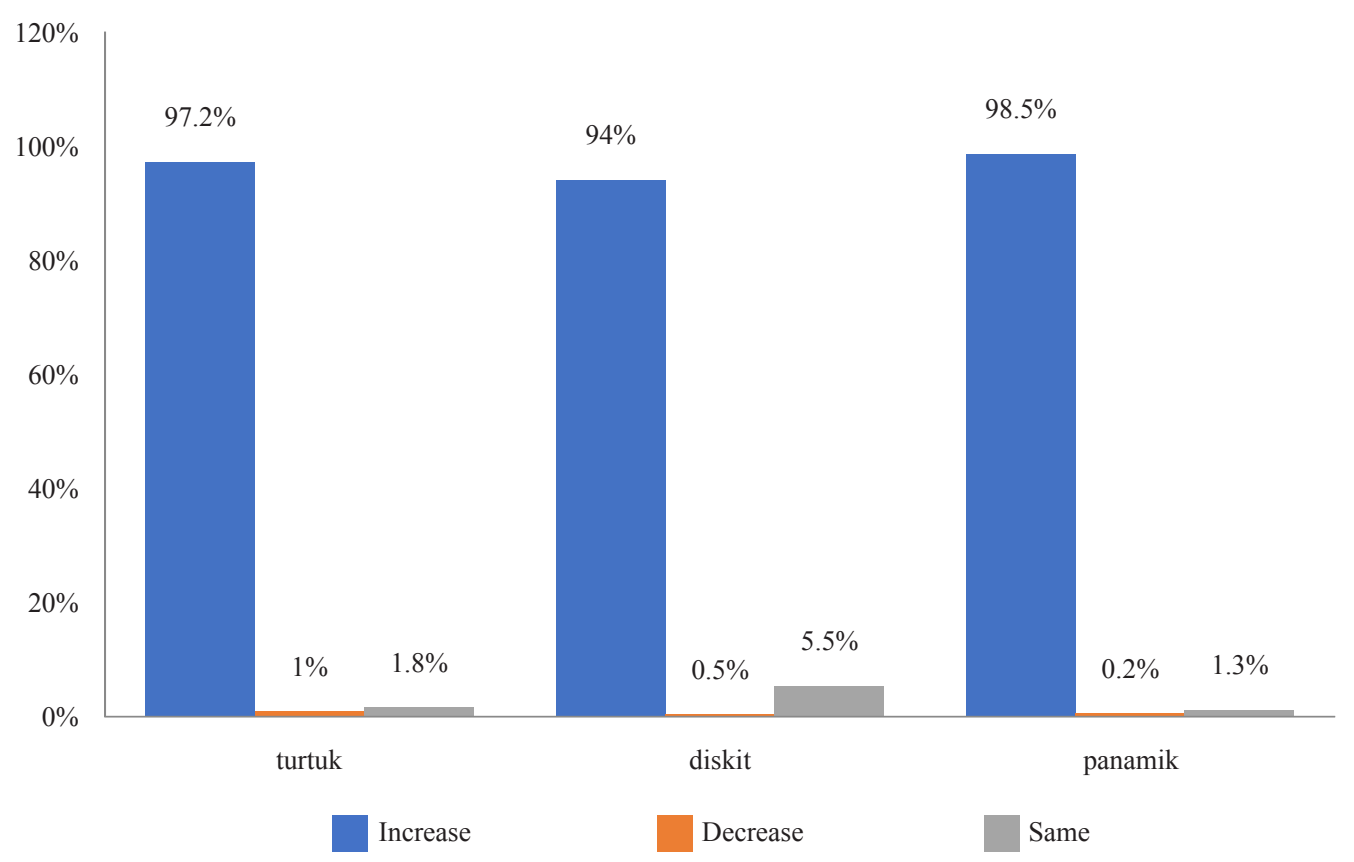

Figure 5. Water vulnerability

The study result shows that almost all the respondents of the three blocks in the study area revealed that water is a core problem and water vulnerability has increased over the year in the Nubra valley (Figure 5). Water scarcity is the biggest issue in each village of the study area particularly for irrigation purposes. Due to the impact of climate change, the pattern of climate variables such as snowfall and rainfall is rather unpredictable and it usually happens untimely, and due to that farmer faces various problems such as shortage of water during sowing season. It has become a serious problem in the study area. Most of the people's household income in the study are fully dependent on farming activities and due to the shortage of water the farmer become more vulnerable and poorer. Thus, the result shows that water vulnerability is higher for the farming activities in the study area and it has adversely affected the poor people in the study area. Thus, it clearly indicates that due to rising temperature, snowfall has declined resulting in reduction of the 
water availability in the study area. So, water availability particularly for irrigation is an indicator of exposure and water is highly vulnerable in each of the village in the study area due to rising temperature. Hence, it is very necessary to take certain active steps to reduce water vulnerability and improve water sustainability in irrigation system in the study area.

\subsection{Farmers' response and adaptation strategies to climate change impacts}

People living in the mountains of the Himalayan region are highly dependent on weather and glacier melts water to do the farming activities. The change in climatic conditions over the years has negatively impacted the agricultural productivity, crop yield, and food supply in the region. People experienced that over the last several years there is irregular rainfall (delayed or shift in rainfall, low rainfall or no rainfall), drastic changes in the frequency and volume of precipitation patterns, low snowfall, and rising temperatures resulted in the low yield of crops and vegetables in the region. Climate change also resulted in increase in natural disasters such as floods, cloudbursts, flash floods caused by land degradation, and soil erosion which has a direct impact on crop productivity and food security. The major changes induced by climate variability as observed by the traditional communities to cope with these changes are presented in (Figure 6). People's perception of the impact of climate change on agricultural productivity, land degradation, availability of water and forest resources is evaluated (Figure 2).

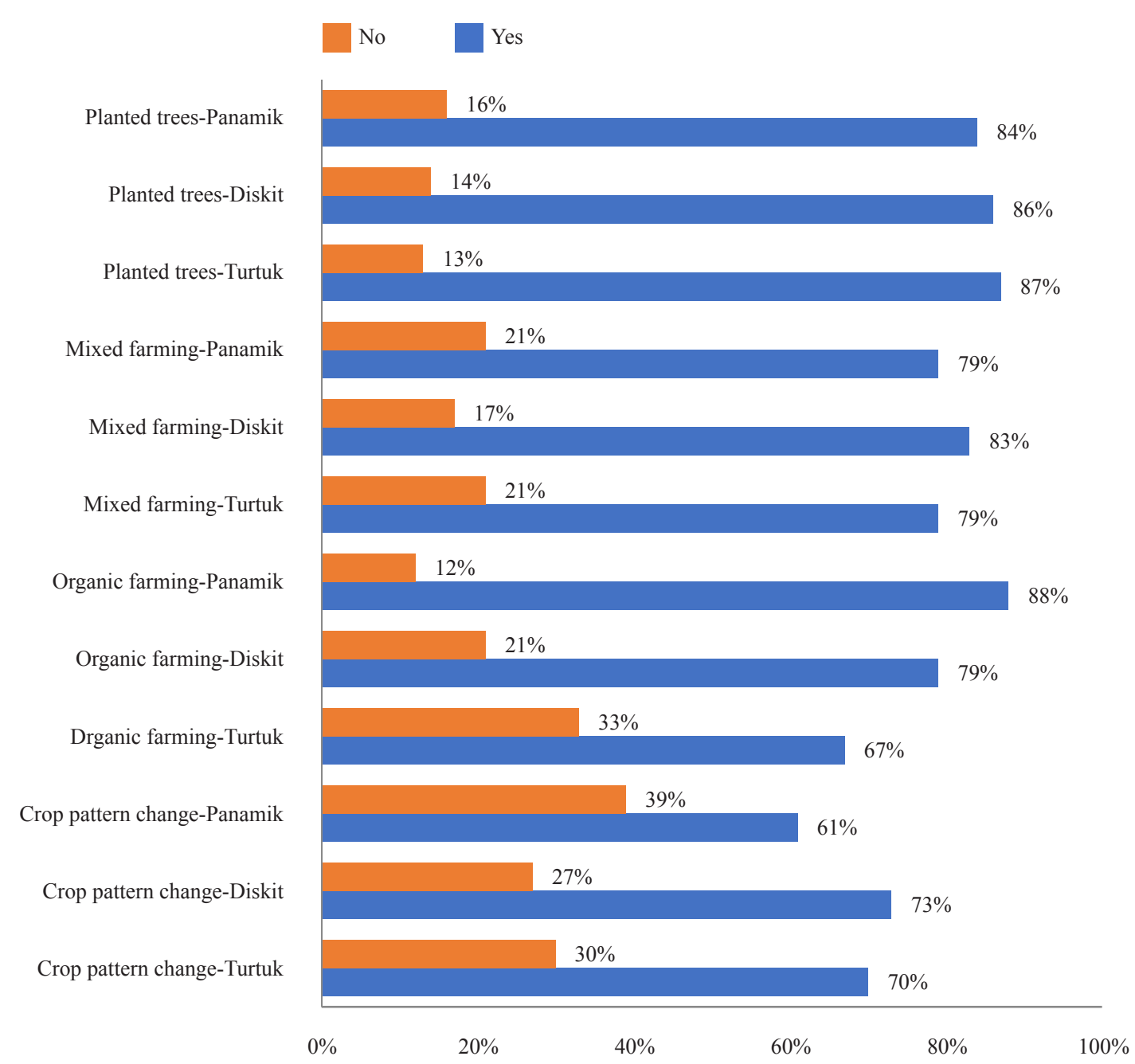

Figure 6. Community response and adaptation to climate change impacts in three selected blocks of Nubra valley viz. Turtuk, Diskit and Panamik Source: Field survey data, 2020 
The study result revealed that $70 \%$ of respondents of Turtuk block, $73 \%$ of respondents of Diskit block, and $61 \%$ of respondents of Panamik block respectively have adopted local strategies of cropping patterns in the study area (Figure 6). Traditional agriculture production has declined due to uncertainty of climatic conditions and the local inhabitants developed their adaptation strategies by using their past experiences and local indigenous knowledge to cope with the changes of climatic factors such as increasing temperature, low rainfall, natural disaster, land degradation and soil erosion (Figure 6). The productivity of traditional crops of food grain such as wheat and barley has declined due to rising temperature and also due to the less availability of water has changed their traditional cropping practices into the mixed cropping system. Due to which they had minimized the production of traditional crops and instead started cultivating cash crops such as Kidney bean (Rajma dal), Len culinaris (Kala masoor), Solanum melongena (Brinjal), Capsicum annuum (Capsicum), Cucumis sativus (Cucumber), Lagenaria siceraria (Bottle gourd), Capsicum frutescens (Chilli) and Brassica oleracea var. italica (Broccoli), to cope with the rising temperature and adapt their cropping practices to alleviate negative impacts and maximize the potential benefits of climate change at the mountain region of Nubra valley.

Floods have frequently been occurred in Nubra valley since the last decade (Table 2) thus, adversely impacting agriculture and forest resources i.e., land degradation, soil erosion, and losses of crops, etc. Local indigenous people had learned to deal with the changing climate and more frequent events. More than $75 \%$ of the respondents of each block practiced that the adaptation strategy of mixed farming to increase soil fertility by using local manure in crops cultivation and to protect the soil erosion (Figure 6). Besides, 67\% respondents of Turtuk block, 79\% respondents of Diskit block, and $88 \%$ respondents of Panamik block revealed that the local population has started practicing organic farming to increase soil water retention/drainage (better response to droughts and floods) and also to avoid land degradation to adapt the impacts of climate change in the region. Furthermore, to adapt to land degradation and soil erosion. The majority of the respondents in each block were planting more trees to cope with climate change (Figure 6).

\section{Discussion}

The scientific information and data regarding the impacts of climate change on the people living in the mountainous region are limited. However, the indigenous people of these mountainous regions felt and experienced the impact of climate change on various economic activities such as livelihoods, lifestyles, and natural resources availability (Sharma et al., 2009). Several indicators of climatic conditions have been changing like increasing temperature, frequent natural disasters, decrease in snowfall and rainfall (Below et al., 2010). The impacts of climate change are a serious threat to those people whose livelihoods are fully reliant on natural resources.

Thus, the perception of local peoples and their indigenous knowledge about climate change is the most significant to improve their local adaptation strategies and to reduce the vulnerability of the key sectors due to the impact of climate change and to uplift their society (Mehta et al., 2010).

In the present study, the majority of the respondents have reported numerous indicators of climate change such as changes in the pattern of precipitation, increase in temperature, disease in crops, seasonal change in rainfall, shifting and adaptation of vegetation, water scarcity, changing pattern of crops, frequent floods, early or late crop maturity.

The impacts of climate change are very serious to the inhabitants of mountain regions especially those living in the Trans-Himalayas due to their fragile ecosystem. The main source of livelihood of the rural people is agriculture, and climate change has directly impacted their agricultural production and indirectly to livelihoods.

One of the greatest impacts of climate change in the study area is the shortfall in the availability of water, rising temperature, and less snowfall in winters. Agriculture is the main occupation of the people of Nubra valley and the main source of irrigation is the melt water from the glaciers. Due to its higher dependence on glacier melt water as it is the only source of water for both irrigation and potable water in the Nubra and the productivity of agricultural production has declined and the local people have become more vulnerable as the availability of water from spring has reduced to a considerable amount due to increasing temperature and less rainfall and snowfall in the region. Hence, water scarcity is a major issue in each village of the study due to increasing temperature. Thus, water requirement particularly for the irrigation purposes is an indicator of exposure and higher vulnerability in the study area.

There are both positive and negative impacts of climate change in the study area. The negative impacts are land degradation, soil erosion, water scarcity, and frequent natural disasters in the hilly regions are a very serious concern. 
New diseases has increased over the year in the traditional crops and fruits such as wheat and barley, apricots, apples and walnuts due to rising temperatures and thus, decline in its productivity. The apricot production is severely affected in many villages of the study area due to the decline in the amount of snowfall and hailstorm in late spring in the form of precipitation as it badly affects the flowering and budding and late snowfall affects the process of pollination of the plants in the hilly region. Therefore, the indicators of traditional crops and fruits is an exposure and highly vulnerable in the study area (Partap et al., 2012).

However, the positive impacts of climate change in the study area are seen in both agriculture and horticulture production such as kidney bean, cabbage, broccoli, capsicum, chili, cucumber, bottle gourd, and other cash crops. These crops are mainly grown because of an increase in the temperatures which was not possible in the past due to extreme weather conditions in the study area. Similar studies have also been found from Urgam and Niti valleys in Uttarakhand (Negi et al., 2017). Thus, all the indicators of cash crops are an adaptive capacity and lower vulnerability to the impacts of climate change. All the indicators of adaptive capacity are the best alternative to reduce the exposure of climate vulnerability and improve resiliency in the study area. Therefore, government should take certain steps to improve their adaptive capacity and to reduce climate vulnerability in the study area.

To make the adaptation strategies are more reliable, replicable, flexible, and resource-conserving in nature, the local adaptation mechanism should be used with scientific knowledge by using modern techniques and tools. The role of traditional knowledge of local indigenous people should be focused more actively in the design of policy and adaptation strategies at the national and global levels. Thus, it is important to understand the local people's traditional knowledge, experienced, and their responses and adaptation strategies to climate change to sustain their livelihood and environment.

\section{Conclusion}

This study was conducted in the Nubra valley of Ladakh to identify the local indigenous people's perception of climate change, its impacts, vulnerabilities, and their adaptation strategies to climate change. The paper asserts that most of the respondents perceived dealing with climatic factors such as changes in temperature, precipitation level, and frequent floods as the most profound climate condition which impacts their livelihoods. In the study area land degradation, severe soil erosion, low agricultural productivity, less water availability and low forest resources are the common climate change-related hazards and impacts. To overcome these challenges, local indigenous people are using different adaptation strategies by utilizing their past experiences such as mixed farming, changes in cropping patterns, organic farming, and planting more trees.

Adaptation strategies are the best way to respond to the ongoing and immediate threats of climate change and to minimize their vulnerabilities. Local people's perception and understanding of climate change can be an important strength to adaptation to climate change though it is hardly taken into consideration by the policymakers at the national and international level. Thus, the syntheses way of approach is more appropriate to adapt the climate change impacts in which people's perceptions and indigenous knowledge with the available scientific knowledge about climate change can bring the more constructive way of methods to increases our capacity for global climate change mitigation and adaptation.

\section{Policy implications}

People living in the hilly regions have been using the local adaptation strategies and mitigation mechanisms to cope up with extreme weather and environmental change over centuries through their traditional knowledge. Organic farming and traditional agricultural practices are very popular in the world due to their higher potential for mitigation and cope up with the impacts of climate change and it has also a greater ability to reducing greenhouse emissions gases like carbon dioxide, methane, and nitrous oxide (Goh, 2011).

However, the policy planners are not giving utmost importance to the usage of traditional knowledge regarding adaptation strategies and mitigation mechanisms. Due to changes in climatic patterns, local people in the study area have started using various local adaptation strategies like changing their crop and cropping patterns to improve their resilience. However, despite having high coping power, traditional crops have been excluded from agricultural programs 
and policies. Hence, there is an urgent need to implement these traditional practices and also need to design appropriate policies towards the impact of climate change on the environment at the grass-root level and to develop a network with governmental projects, NGOs, and other institutions working on climate change to preserve environmental conservation in the Himalayan region.

Effective water governance should be implemented to maintain a well-functioning watersheds and it can improve the resilience of rural communities and their economies as water is the core issue in the study area due to the impacts of climate change. It is important to strengthen local indigenous peoples' knowledge, experiences, innovations, and practices within ecological and social systems to cope up with the impacts of climate change. Sound scientific knowledge together with credible, indigenous knowledge is necessary to support the development and implementation of comprehensive policies and sound adaptation mechanisms. Similarly, an artificial glacier technology should be constructed to mitigate the water scarcity in the sowing time and solar greenhouse low carbon vegetable production should be applied and it is a suitable technique in the fragile environment and ecological harsh climate.

\section{Declaration of conflicting interests}

The authors declared no potential conflicts of interest with respect to the research, authorship and/or publication of this paper.

\section{References}

Aase, T., \& Chapagain, P. (2017). Climate change and the future of Himalayan farming. Oxford University Press, New Delhi.

Belay, A., Recha, J. W., Woldeamanuel, T., \& Morton, J. F. (2017). Smallholder farmers' adaptation to climate change and determinants of their adaptation decisions in the Central, Rift Valley of Ethiopia. Agriculture \& Food Security, 6(1), 24. https://doi.org/10.1186/s40066-017-0100-1

Below, T., Artner, A., Siebert, R., \& Sieber, S. (2010, February). Micro-level practices to adapt toclimate change for African small scale farmers: A review of selected literature. International Food Policy Research Institute. Environment and Production Technology Division. https://www.preventionweb.net/files/12863_IFPRIfeb2010.pdf

Berrang, F. L., Ford, J. D., Lesnikowski, A., Poutiainen, C., Barrera, M., \& Heymann, S. J. (2014). What drives national adaptation? Aglobal assessment. Climatic Change, 124, 441-450. https://doi.org/10.1007/s10584-014-1078

Carman, J. P., \& Zint, M. T. (2020). Defining and classifying personal and household climate change adaptation behaviors. Global Environmental Change, 61, 102062. https://doi.org/10.1016/j.gloenvcha.2020.102062

Chapagain, P. S., Ghimire, M., \& Shrestha, S. (2017). Status of natural springs in the Melamchi region of the Nepal Himalayas in the context of climate change. Environment, Development and Sustainability, 21, 263-280. https:// doi.org/10.1007/s10668-017-0036-4

Chaudhary, P., \& Bawa, K. S. (2011). Local perceptions of climate change validated by scientific evidence in the Himalayas. Biology Letters, 7, 767-770. https://doi.org/10.1098/rsbl.2011.0269

Chevuturi, A., Dimri, A. P., \& Thayyen, R. J. (2018). Climate change over Leh (Ladakh), India. Theoretical and Applied Climatology, 131, 531-545. https://doi.org/10.1007/s00704-016-1989-1

Dannevig, H., \& Hovelsrud, G. K. (2015). Understanding the need for adaptation in a natural resource dependent community in Northern Norway: Issue salience, knowledge and values. Climatic Change, 135, 261-275. https:// doi.org/10.1007/s10584-015-1557-1

Dieye, A. M., \& Roy, D. P. (2012). A study of rural Senegalese attitudes and perceptions of their behavior to the climate. Environmental Management, 50(5), 929-941. https://doi.org/10.1007/s00267-012-9932-4

Falco, S. D., Yesuf, M., Kohlin, G., \& Ringler, C. (2012). Estimating the impact of climate change on agriculture in low-income countries: Household level evidence from the Nile Basin, Ethiopia. Environmental and Resource Economics, 52, 457-478. https://doi.org/10.1007/s10640-011-9538-y

Gao, J., Yao, T. D., Masson, D, V., Steen, L, H. C., \& Wang, W. (2019). Collapsing glaciers threaten Asia's water supplies. Nature, 565(7737), 19-21. https://doi.org/10.1038/d41586-018-07838-4

Goh, K. M. (2011). Greater mitigation of climate change by organic than conventional agriculture: A review. Biological Agriculture and Horticulture, 27, 205-230. https://www.tandfonline.com/loi/tbah20 
Gupta, P., Khanna, A., \& Majumdar, S. (2012). Disaster management in flash floods in Leh, Ladakh. Indian Journal of Community Medicine, 37(3), 185-190. https://doi.org/10.4103/0970-0218.99928

Hewitt, K. (1998). Himalayas Indus streams in the Holocene: Glaciers and landslide interrupt fluvial system. In I. Stellrecht (Ed.), Karakoram-Hindukush-Himalaya: Dynamics of Change (pp. 3-28). Rüdgers Köppe Verlag, Köln.

Hussain, A., Qamar, F. M., Adhikari, L., Hunzai, A. I., Rehman, A. U., \& Bano, K. (2021). Climate change, mountain food systems, and emerging opportunities: A study from the Hindu Kush Karakoram Pamir Landscape, Pakistan. Sustainability, 13, 3057. https://doi.org/10.3390/su13063057

Intergovermental panel on climate change (IPCC). (2018). Global warming of $1.5{ }^{\circ} \mathrm{C}$. Cambridge University Press, United Kingdom.

IPCC. (2019). Climate change and land. The intergovernmental panel on climate change. Geneva, Switzerland.

IPCC. (2014b). Climate change 2014: Impacts, adaptation, and vulnerability-part B: Regional aspects-working group II contribution to the fifth assessment report of the intergovernmental panel on climate change. Cambridge University Press, Cambridge.

IPCC. (2007). Climate change 2007: Impacts, adaptation and vulnerability. Contribution of working group II to the fourth assessment report of the IPCC. Cambridge University Press, Cambridge.

IPCC. (2007a). Climate change 2007: Synthesis report. In R. K. Pachauri, \& A. Reisinger (Eds.), Contrbution of working groups I, II and III to the fourth assessment report of the intergovernmental panel on climate change. IPCC, Geneva, Switzerland.

Jarawura, F. X. (2014). Perceptions of drought among rural farmers in the Savelugu district in the northern Savannah of Ghana. Ghana Journal of Geography, 6, 102-120. http://www.ajol.info/index.php/gjg/article/download/111137/100904

Joshi, P. K., Rawat, B., \& Padilya, H. (2006). Biodiversity characterization in Nubra valley, Ladakh with special reference to plant resources conservation and bioprospecting. Biodiversity conservation, 15(13), 4253-4270. https:// doi.org/10.1007/s10531-005-3578-y

Khanal, U., Wilson, C., Hoang, V. N., \& Lee, B. (2018). Farmers' adaptation to climate change, its determinants and impacts on rice yield in Nepal. Ecological Economics, 144, 139-147. https://doi.org/10.1016/ j.ecolecon.2017.08.006

Kumar, R. A., Zaman, S., Bhattacharyya, S., Banerjee, K., Sengupta, K., Bikash, B. S., \& S. K. (2013). Climate change and sustainable livelihood programmes: A case study from the Indian Sundarbans. The Journal of Ecology, 107, 335-348.

Kumar, G. P., Kumar, R., \& Chaurasia, O. P. (2009). Ethnobotanical studies of Nubra valley-A cold arid zone of Himalaya. Ethnobotanical Leaflets, 2009(6), 9. https://opensiuc.lib.siu.edu/ebl/vol2009/iss6/9

Lechowska, E. (2018). What determines flood risk perception? A review of factors of floodrisk perception and relations between its basic elements. Natural Hazards, 94(3), 1341-1366. https://doi.org/10.1007/s11069-018-3480-z

Liedtke, R., Barros, A., Essl, F., Lembrechts, J. J., Wedegärtner, R. E. M., Pauchard, A., \& Dullinger, S. (2020). Hiking trails as conduits for the spread of non-native species inmountain areas. Biological Invasions, 22, 1121-1134. https://doi.org/10.1007/s10530-019-02165-9

Marzeion, B., Hock, R., Anderson, B., Bliss, A., Champollion, N., \& Fujita, K. (2020). Partitioning the uncertainty of ensemble projections of global glacier mass change. Earth's Future, 8(7), 1-25. https://doi. org/10.1029/2019EF001470

McDowell, J. Z., \& Hess, J. J. (2012). Accessing adaptation: Multiple stressors on livelihoods in the Bolivian highlands under a changing climate. Global Environmental Change, 22(2), 342-352. https://doi.org/10.1016/ j.gloenvcha.2011.11.002

Mehta, P. S., Sharma, A. K, \& Negi, K. S. (2010). Indigenous knowledge system and sustainable development with particular reference to folklores of Kumaun Himalaya, Uttarakhand. Indian Journal of Traditional Knowledge, 9(3), 547-550. http://nopr.niscair.res.in/bitstream/123456789/9791/1/IJTK\%209\%283\%29\%20547-550.pdf

Mertz, O., Mbow, C., Reenberg, A., Genesio, L., Lambin, E. F., D’haen, S., Zorom, M., Rasmussen, K., Diallo, D., Barbier, B., Moussa, I. B., Diouf, A., Nielsen, J. Ø., \& Sandholt, I. (2011). Adaptation strategies and climate vulnerability in the Sudano-Sahelian region of West Africa. Atmospheric Science Letters, 12(1), 104-108. https:// doi.org/10.1002/asl.314

Mitter, H., Larcher, M., Schonhart, M., Stottinger, M., \& Schmid, E. (2019). Exploring farmers' climate change perceptions and adaptation intentions: Empirical evidence from Austria. Environmental Management, 63(6), 804821. https://doi.org/10.1007/s00267-019-01158-7

Negi, V. S., Maikhuri, R. K., Pharswan, D., Thakur, S., \& Dhyani, P. P. (2017). Climate change impact in the western Himalaya: People's perception and adaptive strategies. Journal of Mountain Science, 14, 403-416. https://doi. 
org/10.1007/s11629-015-3814-1

Pandey, R., Aretano, R., Gupta, A. K., Meena, D., Kumar, B., \& Alatalo, J. M. (2017). Agroecology as a climate change adaptation strategy for smallholders of Tehri-Garhwal in the Indian Himalayan Region. Small-scale Forestry, 16(1), 53-63. https://doi.org/10.1007/s11842-016-9342-1

Parry, M. L., Canziani, O. F., \& Palutikof, J. P. (2007). Impacts, adaptation and vulnerability. Contribution of working group II to the third assessment report of the intergovernmental panel on climate change. Cambridge University Press, Cambridge, United Kingdom.

Partap, U., Partap, T., \& Sharma, H. K. (2012). Value of insect pollinators to Himalayan agricultural economies. ICIMOD, Kathmandu, Nepal.

Paudel, B., Gao, J., Zhang, Y., Wu, X., Li, S., \& Yan, J. (2016). Changes in cropland status and their driving factors in the Koshi River Basin of the central Himalayas, Nepal. Sustainability, 8(9), 933. https://doi.org/10.3390/su8090933

Pröbstl-Haider, U., Mostegl, N. M., Kelemen-Finan, J., Haider, W., Formayer, H., Kantelhardt, J., Moser, T., Kapfer, M., \& Trenholm, R. (2016). Farmers' preferences for future agricultural land use under the consideration of climate change. Environmental Management, 58, 446-464. https://doi.org/10.1007/s00267-016-0720-4

Rao, K. S., Maikhuri, R. K., \& Semwal, R. L. (2012). Climate change adaptation andmitigation: Insights from Nanda Devi Biosphere in Indian Himalaya. In K. G. Saxena, L. H. Liang, K. Tanaka, \& S. Takahashi (Eds.), Land management in marginal mountain region: Adaptation and vulnerability to global change. Bishen Singh mahendra Pal Singh, Dehradun, India.

Rufat, S., Fekete, A., Arma, I., Hartmann, T., Kuhlicke, C., Prior, T., Thaler, T., \& Wisner, B. (2020). Swimming alone? Why linking flood risk perception and behavior requires more than "it's the individual, stupid". WIRES Water, 7(5), e1462. https://doi.org/10.1002/wat2.1462

Maikhuri, R. K., Rao, K. S., Patnaik, S., Sexana, K. G., \& Ramakrishnan, P. S. (2003). Assessment of vulnerability of forests, meadows and mountain ecosystems due to climate change. Himalayan Ecology, 11(2). https://www. researchgate.net/publication/237756629

Sharma, E., Chettri, N., \& Tse-ring, K. (2009). Climate change impacts and vulnerability in the Eastern Himalayas, Kathmandu. ICIMOD, MacArthur Foundation. https://www.preventionweb.net/files/14744_climatechangevulnerabilityofmountai.pdf

Sharma, E., Molden, D., Rahman, A., Khatiwada, Y. R., Zhang, L., Singh, S. P., Yao, T., \& Wester, P. (2019). The Hindu Kush Himalaya assessment: Mountains, climate change, sustainability and people. Springer International Publishing.

Shrestha, A. B., \& Aryal, R. (2011). Climate change in Nepal and its impact on Himalayan glaciers. Regional Environmental Change, 11, 65-77. https://doi.org/10.1007/s10113-010-0174-9

Simelton, E., Quinn, C. H., Batisani, N., Dougill, A. J., Jen, C., Fraser, E. D. G., Mkwambisi, D., Sallu, S., \& Stringer, L. C. (2013). Is rainfall really changing? Farmers' perceptions, meteorological data and policy implications. Climate and Development, 5(2), 37-41. https://doi.org/10.1080/17565529.2012.751893

Tashi, M. (2010). Understanding the transformation in Ladakh. Issues, threats and early warnings, institute of peace and conflict studies, New Delhi, India.

Tripathi, R., Sengupta, S. K., Patra, A., Chang, H., \& Jung, I. W. (2014). Climate change, urban development, and community perception of an extreme flood: A case study of Vernonia, Oregon, USA. Applied Geography, 46, 137146. https://doi.org/10.1016/j.apgeog.2013.11.007

Van, V. A. M., \& Steg, L. (2019). Meta-analysis of factors motivating climate change adaptation behavior. Nature Climate Change, 9(2), 158-163. https://www.nature.com/articles/s41558-018-0371-y

Weber, E. U. (2010). What shapes perceptions of climate change. WIREs, 1, 332-342. https://doi.org/10.1002/wcc.41

Williamson, S. N., Zdanowicz, C., Anslow, F. S., Clarke, G. K. C., Copland, L., Danby, R. K., Flowers, G. E., Holdsworth, G., Jarosch, A. H., \& Hik, D. S. (2020). Evidence forelevation dependent warming in the St. Elias Mountains, Yukon, Canada. Journal of Climate, 33, 3253-3269. https://doi.org/10.1175/JCLI-D-19-0405.1

$\mathrm{Xu}$, J., \& Grumbine, R. E. (2014). Building ecosystem resilience for climate change adaptation in the Asian highlands. Wiley Interdisciplinary Reviews, 5(6), 709-718. https://doi.org/10.1002/wcc.302 